\title{
APPLIED RESEARCH ON STRATEGIC MANAGEMENT OF SMES IN ROMANIA IN THE DIGITAL AGE
}

\author{
Dan POPESCU*, Cristina STATE*, Livia TOANCA**, Ioana PAVEL* \\ * The Bucharest University of Economic Studies, Romania \\ ** Liv Consulting, Los Angeles, USA \\ dan.popescu@man.ase.ro, cristina.state@man.ase.ro, livia.toanca@gmail.com \\ iioanapavel@yahoo.com
}

\begin{abstract}
Technological social and cultural changes generated by the digital age have a significant impact on both individual and society as a whole [1]. Is the context in which our research aimed at revealing the extent to which SMEs in our country are prepared to cope with these changes and can adapt to an environment increasingly turbulent and unpredictable [2]. Based on the three hypotheses of our scientific approach, the method used was the quota for proportional distribution by counties, respectively the optimal-layered model for the distribution by fields of activity. As a means of investigation we used a questionnaire with 26 questions answered by 598 SMEs, the purpose being represented by identifying, on the one hand, the used methods of strategic management and, on the other hand, the uptake of digital means by them. The responses from the distribution of the questionnaire were analyzed by various statistical and econometric methods. In a first stage we used descriptive statistics to identify peculiarities of respondents to compare different homogeneous groups. In the second stage of analysis to determine statistical deductive conclusions, we used the analysis of variance, correlation and linear regression and ANOVA using SPSS software for Windows 16.0. Following validation of the research hypotheses, in the end of the work we formulated a series of proposals to improve the strategic management of SMEs in Romania in the digital age.
\end{abstract}

\section{Keywords: digital age, digital services, SME, strategic management}

\section{Introduction}

Although we are in the boom and supremacy of the digital era [3], IT is ranked 5 among the priorities of SME's managers in Romania, after marketing activities, diversification of production, acquisition of new technology and training of the labor force [4].

Given that innovative practices offer a wealth of opportunities and a growing scope for SMEs, they are faced with new challenges [5].

The theory of free innovations proposed in 2003 by Chesbrough argues that, during the innovation process, businesses need to take into account innovative ideas and resources, both internally and externally, integrating their capabilities and resources, and then exploiting through multiple internal and external market channels for the purpose of technological advancement. Because barriers between the firm and the environment have become more permeable, innovations can be easily transferred, both internally and externally [6].

\section{Methodology and research hypothesis \\ Our paper tends to address the strategic management of SMEs in the context of the digital era and is aimed at highlighting the need to use new methods of strategic thinking to help SMEs maintain their viability on the global market. This market is characterized, mainly, by swift and considerable changes[7],}


that are due to the galloping innovation of the digital era [8].

We used the questionnaire as a data collection technique focusing on:

- the degree of adaptation of SMEs from Romania to the new concepts, strategy and strategic management;

- the extent to which SMEs from Romania have adopted new advancements in the digital field;

- the differences between the fields of activity of the SMEs as regards the degree of digital adoption;

- the perception of the digital field, by SMEs from Romania, as a transforming force of the external organizational environment;

For the questionnaire, distributed by over 160 thousand SMEs from Romania, we collected 598 answers.

The questionnaire (accessible on the link $<$ https://goo.gl/BK9qKu>), was distributed by e-mail to more than 160 thousand SMEs from Romania. The method used was that of proportional quotas for the distribution of the sample by geographical area and the optimum stratified sampling method for distribution of the sample by industry [9].

The questionnaire, included 26 questions, whose purpose was to identify both strategic management methods used by the SMEs from Romania and the degree of adoption of digital assets thereof.

The questions in the survey were answered by 643 organizations, 598 of which fall into the category of SMEs. They were distributed, representatively, according to optimum stratified model over the following business areas: information and communications, tourism, industry, construction, marketing, transport; services.

As a result of the expertise gained in the process of identifying the main tendencies of the development of digital and strategic management of SMEs in the context of the digital era, we formulated the following working hypotheses:

Hypothesis 1 (H1): SMEs from Romania have not adopted yet the new digital technologies required to obtain competitiveness on the world market;

Hypothesis 2 (H2): Strategic management of SMEs from Romania requires a series of major transformations, which should help increase both the prosperity and the probability of their survival in the digital era;

Hypothesis 3 (H3): Digital perception viewed as a transforming force of the business environment by the SMEs from Romania is reduced, the latter not realising the real need for change.

\section{Results}

We have turned to the regression analysis to investigate whether and how there is a link between the frequency of external evaluation and the frequency of reevaluation and adaptation of the strategy. In this context, we proceeded to establish the following 8 independent variables:

$\checkmark$ frequency of the competitors' evaluation;

$\checkmark$ frequency of customer evaluation;

$\checkmark$ frequency of suppliers' evaluation;

$\checkmark$ frequency of labor assessment;

$\checkmark$ frequency of the evaluation of the political-legislative environment;

$\checkmark$ frequency of economic environment assessment;

$\checkmark$ frequency of socio-cultural environment assessment;

$\checkmark$ frequency of the evaluation of the technological environment.

As an independent variable, we set the frequency of organizational adaptation and re-evaluation of the strategy.

The results of the regression analysis are shown in table no. 1 and in table no. 2. 
Table .no 1: Model summary

\begin{tabular}{|c|c|c|c|c|c|c|c|c|c|c|}
\hline \multirow[b]{2}{*}{ Model } & \multirow[b]{2}{*}{$R$} & \multirow[b]{2}{*}{$\begin{array}{c}R \\
\text { Square }\end{array}$} & \multirow{2}{*}{$\begin{array}{c}\text { Adjusted } R \\
\text { Square }\end{array}$} & \multirow{2}{*}{$\begin{array}{c}\text { Std. Error of the } \\
\text { Estimate }\end{array}$} & \multicolumn{5}{|c|}{ Change Statistics } & \multirow[b]{2}{*}{$\begin{array}{l}\text { Durbin- } \\
\text { Watson }\end{array}$} \\
\hline & & & & & $\begin{array}{l}R \text { Square } \\
\text { Change }\end{array}$ & $\begin{array}{c}F \\
\text { Change }\end{array}$ & $d f 1$ & $d f 2$ & $\begin{array}{l}\text { Sig. F } \\
\text { Change }\end{array}$ & \\
\hline 1 & $.218^{\mathrm{a}}$ & .047 & .028 & 1.032 & .047 & 2.465 & 94 & 445 & .009 & 1.993 \\
\hline
\end{tabular}

a. Independent (constant) variables are considered the frequencies with which they are evaluated: the technological environment; workforce; customers; The socio-cultural environment; providers; competitors; The economic environment; The international environment; The political-legislative environment b. Dependent variable: frequency of re-evaluation and adaptation of the organizational strategy

Table no.2: ANOVA

\begin{tabular}{|ll|c|c|c|c|c|}
\hline \multicolumn{1}{|c|}{ Model } & Sum of Squares & $d f$ & Mean Square & $F$ & Sig. \\
\hline \multirow{4}{*}{1} & Regression & 23.619 & 9 & 2.624 & 2.465 & $.009^{\mathrm{b}}$ \\
& Residual & 473.687 & 445 & 1.064 & & \\
& Total & 497.305 & 454 & & & \\
\hline
\end{tabular}

a. Dependent variable: frequency of re-evaluation and adaptation of the organizational strategy;

b. Independent (constant) variables are considered the frequencies with which they are evaluated: the technological environment; workforce; customers; The socio-cultural environment; providers; competitors; The economic environment; The international environment; The political-legislative environment

The results of the regression analysis (shown in tab.no.1 and tab.no. 2) indicate the existence of a statistically significant relationship between the set of predictive indicators and the criterion variable $(\mathrm{F}=$ 2.565; $\mathrm{p} \& 1 \mathrm{t} ; 0.05)$.

Taking into account the value of the multiple correlation coefficient $(\mathrm{R}=$ $0,218)$, it can be concluded that there is a small correlation between the frequency of the external evaluation by the Romanian SMEs and the frequency of adaptation and the re-evaluation of the organizational strategy by them.
In the next step, we investigated the relationship between environmental prediction and the duration of the strategy.

The $t$ (t-test) independent test was used to investigate whether there were significant statistical differences between the average values of the duration of the strategy between the subjects who gave the "yes" and "no" answers to the question of predicting each element of the external organizational environment. We performed 9 such independent tests as the one that follows bellow.

TEST 1: Predicting competitors

Table no. 3: Group statistics

\begin{tabular}{|c|c|c|c|c|c|}
\hline & PV20.1 & $N$ & Mean & Std. Deviation & Std. Error Mean \\
\hline \multirow{2}{*}{ Strategy duration } & Yes & 357 & 2.41 & 1.587 & .084 \\
& No & 159 & 1.60 & 1.463 & .116 \\
\hline
\end{tabular}

Where: PV20.1 is the prediction of competitors (the competitive environment) 
Table no. 4: Independent test samples

\begin{tabular}{|c|c|c|c|c|c|c|c|c|c|c|}
\hline & \multicolumn{2}{|c|}{$\begin{array}{l}\text { Levene's Test } \\
\text { for Equality } \\
\text { of Variances }\end{array}$} & \multicolumn{7}{|c|}{ t-test for Equality of Means } \\
\hline & & \multirow[t]{2}{*}{$F$} & \multirow[t]{2}{*}{ Sig. } & \multirow[t]{2}{*}{$t$} & \multirow[t]{2}{*}{$d f$} & \multirow[t]{2}{*}{$\begin{array}{c}\text { Sig. } \\
\text { (2-tailed) }\end{array}$} & \multirow[t]{2}{*}{$\begin{array}{c}\text { Mean } \\
\text { Difference }\end{array}$} & \multirow[t]{2}{*}{$\begin{array}{l}\text { Std. Error } \\
\text { Difference }\end{array}$} & \multicolumn{2}{|c|}{$\begin{array}{c}95 \% \text { Confidence } \\
\text { Interval of the } \\
\text { Difference }\end{array}$} \\
\hline & & & & & & & & & Lower & Upper \\
\hline \multirow{2}{*}{$\begin{array}{c}\text { Durata } \\
\text { strategiei }\end{array}$} & $\begin{array}{c}\text { Equal } \\
\text { variances } \\
\text { assumed }\end{array}$ & 1.460 & .227 & 5.431 & 514 & .000 & .802 & .148 & .512 & 1.093 \\
\hline & $\begin{array}{c}\text { variances } \\
\text { not assumed }\end{array}$ & & & 5.603 & 327.105 & .000 & .802 & .143 & .521 & 1.084 \\
\hline
\end{tabular}

Through the econometric and the descriptive analysis of the results obtained after the collection of the responses, we checked the validity of the three hypotheses and we reached the following conclusions:

- $H 1$ (SMEs from Romania have not adopted yet, the new digital technologies necessary for obtaining global market competitiveness) is confirmed. Supporting arguments for this conclusion are as follows:

- the majority of SMEs from Romania have not yet adapted their own website to the exigency of mobile technology (only 13\% of them have a website adapted to these requirements);

- there is a big carelessness regarding the collection of useful information about their own customers, in circumstances where the overall market is headed with quick steps towards the phenomenon of customization of tenders;

- only a third of the SMEs provides, regularly, to its own employees the opportunity to develop professionally through trainings in various fields of activity, while another third says that it does not consider it necessary to instruct their own human resources in the field of ICT.

We concluded that SMEs in our country are in need of quick acceleration of the adoption of the digital means, so that they could quickly become competitive on the global market.

- H2 (strategic management of SMEs from Romania requires a major transformation, which should result in increasing prosperity and the probability of their survival to the demands of the digital era) is confirmed, because:

- Although there is a significant statistical correlation between the use of methods of swift analysis, of testing and of experimentation and the frequency of reassessment and adaptation of strategies to environmental requirements, SMEs do not resort to such methods;

- SMEs in our country study and/or adapt their strategy (in case they have it) only when they are required to do so, for example, to comply with the laws in force;

- only $16 \%$ of SMEs declared that they had drawn up strategies for 3-5 years;

- the percentage of SMEs that do not have a strategy varies, depending on the answers to each question (I used reformulation in an attempt to get an image as close to reality as possible), but it is higher than the quota of $10 \%$;

- $H 3$ (the perception of the digital as the transforming force of the business environment is still low, the latter not realising the need to change) was ruled out, at least partly by the answers of participants in the study who, in a percentage of over $70 \%$, consider that the digital era is causing major changes to the competitive environment, to the behavior of the customers and of suppliers and to the environment, while in a percentage of over $50 \%$ it changes the economic environment, labour employment and international environment.

\section{Conclusions}

As result of our findings, we formulated the 
following conclusions of the study:

1. The hypothesis relating to the adoption of digital technologies by SMEs was validated (H1), SMEs adopting digital means in a low degree compared to large enterprises. The degree of adoption of digital means of the SMEs in Romania is still low, as they did not manage to implement the new digital technologies required to obtain digital competitiveness on the global market;

2. Getting competitive advantages is usually the result of strategic management of entrepreneurial success and the digital field, as a transforming force of businesses, has the potential to facilitate this process [11].

3. The gap in terms of the adoption of the digital means by the SMEs from Romania places them in the disadvantageous situation of not succeeding in being competitive on a global level. As the changes brought about by the digital era are imminent, this fact jeopardizes the very future of our national economy [12];

4. However, although they perceive it as a digital force transforming the business environment, SMEs from Romania do not have a long-term strategy. In this context, the only element of the environment that triggers a strong causation in favour of the reassessment and adaptation of the strategy is established (even imposed) by the political and legislative environment;

5. SMEs from Romania do not use rapid methods of analysis, testing and experimentation, in order to minimize the uncertainty of the external environmental factors of the organization, factors they cannot preview.

\section{Proposals}

From the analysis and interpretation of results, as well as from the discovery of the research results, we formulated the following proposals that could be adopted on the micro and the macroeconomic level, both nationally and internationally:

\section{A. Proposals for the macro level}

1. Encouraging investments in infrastructure networks and digital services. In this context, an extremely important role can be played by collaboration (partnerships), the privatepublic type, which may ensure the continuing rapid growth of the digital economy, globally;

2. Facilitating access to sources of financing for SMEs. Encouraging new sources of financing such as, micro-loans, "business angels" investments, business accelerators, crowdfunding and crowd-investing, all these types of investments can become solutions that might contribute decisively to a more dynamic and timely financing of SMEs;

3. Encouraging the increase in the number of incubators and virtual business accelerators. In this context, Law No. 102/2016 is a first legislative step to encouraging SMEs from Romania;

4. Introducing up-to-date digital technologies and encouraging technological creativity in schools;

5. Developing governmental programmes to encourage partnerships between universities and SMEs with the goal to ensure the transfer of knowledge. Programs and projects co-financed by the Government and SMEs could be created for specified periods of time, where new graduates, having access to academic resources, can be part of the improvement performance projects of SMEs.

B. Proposals for the micro level, regarding the strategic adaptation of SMEs to the digital era

1. Developing and implementing a system of periodic evaluation and forecasting of the organizational environment. The ability to "see" or to "predict" the environment can be gained only by practice and by sustained effort. The SMEs that will be able to enforce their own discipline of assessing periodically the environment and of developing forecasts, will be able to increase substantially their chances of success;

2. Using more testing and rapid divergent experimentation. The digital era has reduced costs associated with testing and rapid experimentation, and SMEs can create, with minimal resources, concepts, products or minimum viable services, unfinished, which can be made available to a relevant group of customers from whom they can obtain real feedback;

3. Training employees on a regular basis in different areas and maintaining a flexible 
organisational structure;

4. Exploring, continuously, new innovative business models;

5. Using crowdsourcing anywhere possible;

6. Collaborating and co-opetition (collaboration with the competition), especially given the conditions when aggressive, confrontational actions are proven to be losers by results; 7. Adopting a new model of strategic management for SMEs.

NEW MODEL OF STRATEGIC MANAGEMENT OF SMES IN THE DIGITAL ERA

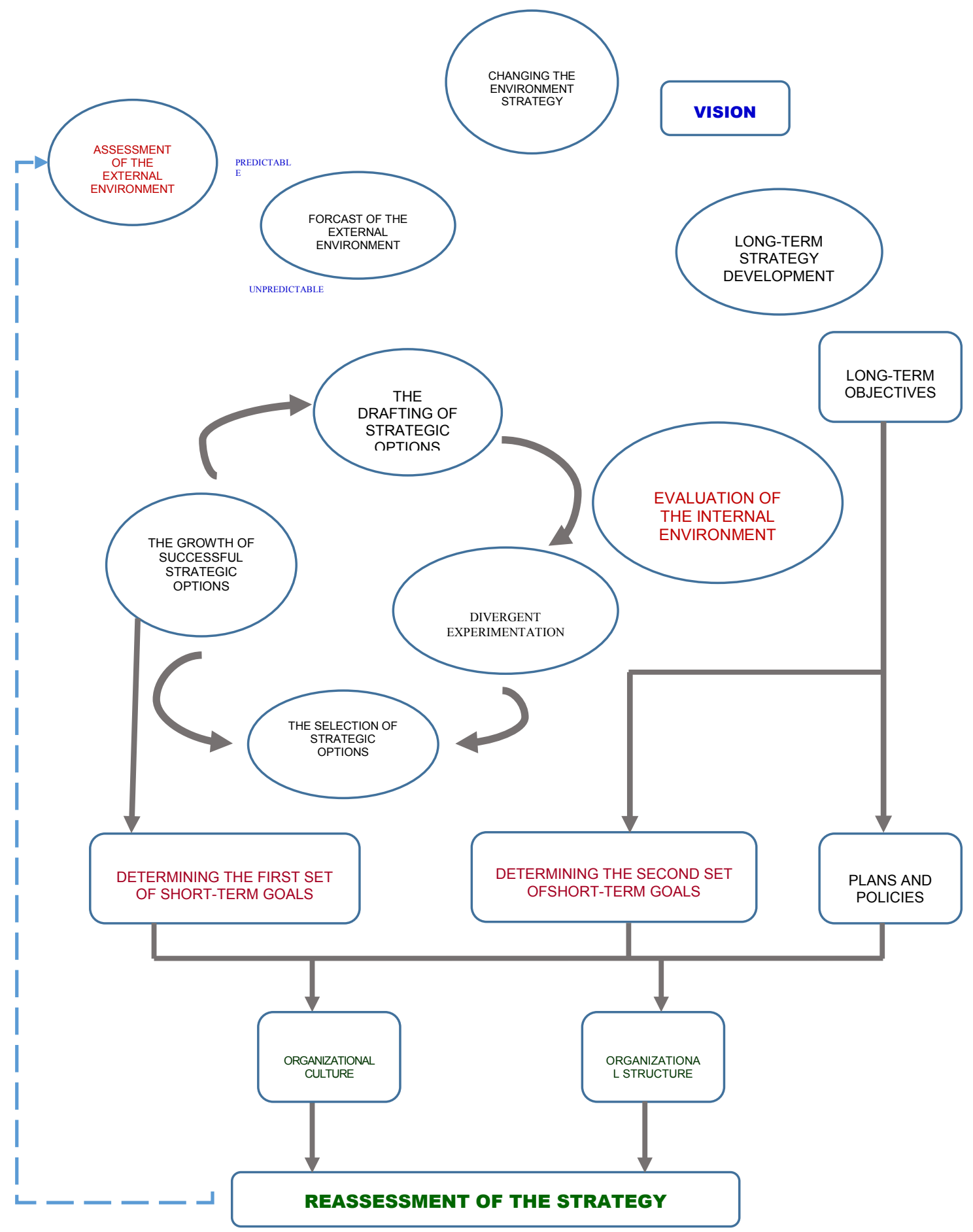

Source: made by authors 


\section{References}

[1] Drucker, P. The Practice of Management $-5^{\text {th }}$ Edition. New York: Harper\&Row, 2006

[2] Christensen, C. The Innovator's Dilemma: When New Technologies Cause Great Firms to Fail (Management of Innovation and Change). Boston: Harvard Business Review Press, 2015

[3] Kurzweil, R. The Age of Spiritual Maschines: When Computers Exceed Human Intelligence. London: Penguine Books, 2000

[4] x x x CNIPMMR - Carta Albă a IMM-urilor din România, Ediţia 2016

[5] Zhang, J. \& Chen, L. "Review of SMEs Open Innovation Performance", American Journal of Industrial and Business Management 4(12): 716-720, 2014

[6] Chesbrough, H.W. New Frontiers in Open Innovation. Oxford University Press, 2015

[7] Reves, M., Haanes, K. \& Sinha, J. "Your Strategy Needs a Strategy", Harvard Business Review 90/(9):76-83, 2012

[8] Schimdt, E. \& Cohen, J. The New Digital Age: Reshaping the Future of People, Nations and Business. MP3CD. Brilliance Audio - Una edition (April 8, 2014), 2014

[9] Magretta, J. "Why Business Model Matter", Harvard Business Review 5/May, 2002

[10] http://www.andreimarga.eu/viata-in-era-digitala/

[11] http://www.sloanreview.mit.edu/projects/ strategy-drives-digital-transformation/

[12] Osterwalder, A. (2010). Business Model Generation: A Handbook For Visionaries, Game Changers, And Challengers. New York: Wiley 